\title{
Correction to: Extensive aplasia cutis congenita associated with cephalocranial disproportion and brain extrusion
}

\author{
Farbod Torkamand $^{1} \cdot$ Aryan Ayati $^{1} \cdot$ Zohreh Habibi $^{1}$ (I) $\cdot$ Farideh Nejat ${ }^{1}$
}

Published online: 18 July 2019

(C) Springer-Verlag GmbH Germany, part of Springer Nature 2019

\section{Correction to: Child's Nervous System https://doi.org/10.1007/s00381-019-04188-y}

The original version of this article unfortunately contained an error. The author apologizes for having communicated a wrong name: "Forbid Torkamand" should be in fact "Farbod Torkamand". Given in this article is the correct author name.

The original article has been corrected.

Publisher's note Springer Nature remains neutral with regard to jurisdictional claims in published maps and institutional affiliations.

The online version of the original article can be found at https://oi.org/ 10.1007/s00381-019-04188-y

\section{Zohreh Habibi}

z-habibi@sina.tums.ac.ir

1 Department of Neurosurgery, Children's Medical Center, Tehran University of Medical Sciences, No 62, Qarib St., Keshavarz Blvd., Tehran 1419733151, Iran 